\title{
Registration of 14 Improved Tropical Musa Plantain Hybrids with Black Sigatoka Resistance
}

\author{
Dirk Vuylsteke', Rony Swennen ${ }^{2}$, and Rodomiro Ortiz ${ }^{3}$ \\ Plantain and Banana Improvement Program, International Institute of Tropical \\ Agriculture, Onne Station, PMB 5320, Ibadan, Nigeria
}

Additional index words. banana, breeding, tetraploid, Mycosphaerella fijiensis

Plantain (Musa spp., AAB group), a triploid $(2 n=3 x=33)$ giant perennial herb, is a natural interspecific hybrid between the two wild species $M$. acuminata Colla and $M$. balbisiana Colla, which contributed the A and $\mathrm{B}$ genomes, respectively. Black sigatoka (Mycosphaerella fijiensis Morelet), an airborne fungal leaf spot disease, is the major constraint to plantain production worldwide. The dispersion of its spores by wind and water makes plant quarantine measures ineffective. The pathogen causes severe leaf necrosis in plantain, resulting in yield losses of 33\% to $50 \%$ (Gauhl et al., 1993; Stover, 1983). All plantain cultivars, and some of the most popular banana cultivars of East Africa, are susceptible to black sigatoka (Swennen and Vuylsteke, 1991). Fungicides to control the disease are available, but their use is not feasible in the resource-poor smallholdings where the crop is grown in Africa. Moreover, fungicide applications pose a health hazard in village homesteads and create an environmental risk to the fragile ecosystem of Africa's humid forest. Therefore, durable host-plant resistance is considered the most appropriate option for black sigatoka control.

The International Institute of Tropical Agriculture (IITA) has a mandate to develop improved germplasm of plantain and banana and to distribute it for subsequent testing and

Received for publication 2 Nov. 1992. Accepted for publication 20 Apr. 1993. We thank Leo Oragwa for technical assistance in embryo culture and Gillian Eggleston and Mike Ogburia for undertaking the preliminary consumer acceptability studies. We acknowledge the International Network for the Improvement of Banana and Plantain for making available diploid male parents. The International Institute of Tropical Agriculture (IITA) is a nonprofit organization and is a member of the Consultative Group on International Agricultural Research. Its international mailing address is IITA, c/o L.W Lambourn and Co., Carolyn House, 26 Dingwall Rd., Croydon CR9 3EE, England. The cost of publishing this paper was defrayed in part by the payment of page charges. Under postal regulations, this paper therefore must be hereby marked advertisement solely to indicate this fact.

'Program Leader and Tissue Culturist/Breeder. ${ }^{2}$ Agronomist/Breeder. Current address: Catholic Univ. of Leuven, Laboratory of Tropical Crop Husbandry, Kardinaal Mercierlaan 92, 3001 Heverlee, Belgium.

${ }^{3}$ Breeder/Geneticist. use by African countries. Plantain and banana are generally considered intractable in terms of genetic improvement. However, from 1987 to 1992 , the plantain breeding program at IITA has developed several plantain clones that combine high yield with resistance to black sigatoka. This improved germplasm is ready for distribution to national agricultural programs.

\section{Origin}

The tropical Musa plantain hybrids (TMPx) with black sigatoka resistance are tetraploid $\mathrm{F}$, progenies derived from interspecific interploidy crosses. The female parents were the locally adapted but black-sigatoka-susceptible AAB 'French' plantain cultivars $(2 \mathrm{n}=3 \mathrm{x}=$ 33) Obino 1'Ewal and Bobby Tannap from Nigeria and Cameroon, respectively (Swennen, 1990). These cultivars were selected as parents in 1987 due to their relatively high female fertility (Swennen and Vuylsteke, 1988, 1993). The diploid $(2 n=2 x=22)$ male parents, used as sources of black sigatoka resistance, were the wild banana 'Calcutta4' (AA,M.acuminata ssp. burmannica) and 'Pisang lilin' (AA, derived from $M$. acuminata ssp. malaccensis) from Burma (Myanmar) and Malaysia, respectively. 'Calcutta 4' has true-seeded fleshless nonparthenocarpic fruits because it lacks one of three dominant complementary genes for parthenocarpy (Simmonds, 1953). 'Pisang lilin', a translocation heterozygote (Hutchinson, 1966), has edible parthenocarpic fruits.

The $3 \mathrm{x} \times 2 \mathrm{x}$ crosses, which led to the production of the TMPx germplasm, were made in 1988 and 1989. Seeds were harvested and embryos germinated in vitro (Vuylsteke et al., 1990). Tetraploid (AAAB) and diploid progenies were identified by root-tip chromosome counts. The $4 \mathrm{x}$ progenies resulted from the union of unreduced $(2 n=3 x)$ eggs from the female parents with normal $(n=x)$ pollen from the male parents (Vuylsteke et al., 1993).

More than 250 hybrids were field-established in early evaluation trials in 1989-90. From these, 20 tetraploids were selected for in vitro multiplication and further field evaluation in preliminary yield trials and in comparison with their plantain parents (Vuylsteke et al., 1993). The selection criteria were partial resistance to black sigatoka and adequate agronomic and fruit quality characteristics. Geno- type response to black sigatoka infection was measured using the method of Vakili (1968) which consists of recording the youngest leaf spotted (YLS), counting down from the first (top) unfurled leaf, on plants at flowering, which is the time when leaf production stops. High YLS values indicate the presence of more fully functional leaves on the plant and, hence, greaterresistance to the fungus. Growth and yield variables were evaluated at flowering and at harvest, as described by Swennen and De Langhe (1985). The TMPx genotypes were compared statistically with the respective fungicide-treated plantain parents using critical values of Student's t distribution, adjusted by Sidak's multiplicative inequality (Sokal and Rohlf, 1981). After intensive testing from 1989 to 1992 at Onne, IlTA's highrainfall station in the humid forest zone near Port Harcourt, Nigeria, a total of 14 TMPx genotypes were selected further for distribution to national programs in Africa.

\section{Description and performance}

The TMPx clones are identified by their original cross/progeny number (Table 1). All the TMPx have higher levels of black sigatoka resistance than their susceptible plantain parents, as determined by an evaluation of YLS. Selected TMPx may show a gain of up to six leaves without black sigatoka spotting when compared with the fungicide-treated parents (Table 1). Host response to black sigatoka in the partially resistant TMPX germplasm is based on slower or delayed disease development. The ensuing reduction of leaf spot damage results in a larger functional leaf area during fruit filling time and, thus, larger and heavier fruit (Gauhl et al., 1993). Black sigatoka resistance results from the interaction between a major recessive gene and two modifiers with additive effects (Ortiz and Vuylsteke, 1992).

The tetraploid hybrids generally show a close phenotypic resemblance to their respective female plantain parents. All the hybrids display parthenocarpic fruit development, and all but one, 'TMPX 4698-1', have erect fruit orientation, as do their plantain parents. Most hybrids have a pendulous bunch orientation, except 'TMPx 582-4' and 'TMPx 4744-1', which have a subhorizontal bunch. Neutral flowers are deciduous in all hybrids, except 'TMPX 4744-1', which has semipersistent neutral flowers. TMPx 548-9,582-4,4479-1, 4698-1,4744-1, 5511-2, 6930-1, and 7002-1 exhibit male bud imbrication. The TMPx germplasm develop one or two suckers freely, while further suckering is inhibited. Regulated suckering is a highly desirable trait for perennial plantain production. The TMPX germplasm develop dramatically less black sigatoka leaf spot damage than their plantain parents, evidence of either greater resistance or less susceptibility (Vuylsteke et al., 1993). In contrast to the plantain parents, which are female-fertile but male-sterile, the hybrids are female- and male-fertile and can be used as parents to produce secondary triploid hybrids by $4 \mathrm{x} \times 2 \mathrm{x}$, and vice versa, crosses.

The TMPx germplasm is shorter and has a 
Table 1. Agronomic evaluation of 14 selected TMPx clones at Onne, Nigeria, from 1990 to $1992 .{ }^{2}$

\begin{tabular}{|c|c|c|c|c|c|c|c|c|}
\hline Genotype & Parents ${ }^{x}$ & $\begin{array}{c}\text { Youngest } \\
\text { leaf } \\
\text { spotted at } \\
\text { flowering }\end{array}$ & $\begin{array}{l}\text { Plant } \\
\text { ht } \\
(\mathrm{cm})\end{array}$ & $\begin{array}{c}\operatorname{HTS}^{y} \text { at } \\
\text { harvest } \\
(\mathrm{cm})\end{array}$ & $\begin{array}{c}\text { Fruit } \\
\text { filling time } \\
\text { (days) }\end{array}$ & $\begin{array}{c}\text { Bunch } \\
\text { wt } \\
\text { (kg) }\end{array}$ & $\begin{array}{l}\text { No. } \\
\text { hands }\end{array}$ & $\begin{array}{l}\text { No. } \\
\text { fruits }\end{array}$ \\
\hline TMPx 548-4 & $\mathrm{OL} \times \mathrm{C} 4$ & $10.0^{* * *}$ & $330^{* * *}$ & $280^{* *}$ & $126^{* *}$ & $16.7^{* *}$ & $6.5^{* *}$ & $103^{* *}$ \\
\hline TMPx 582-4 & BT $\times$ C4 & $11.0^{* *}$ & $300^{* *}$ & $270^{* *}$ & $135^{* *}$ & $14.3^{\text {vs }}$ & $7.5^{\mathrm{Ns}}$ & $124^{* * *}$ \\
\hline TMPx $1621-1$ & $\mathrm{OL} \times \mathrm{C} 4$ & $7.5^{\mathrm{Ns}}$ & $340^{* *}$ & $280^{* * *}$ & $120^{* * *}$ & $13.8^{* * *}$ & $6.5^{* *}$ & $90^{\text {ws }}$ \\
\hline TMPx 1658-4 & $\mathrm{OL} \times \mathrm{Pl}$ & $9.3^{* *}$ & $320^{* *}$ & $185^{\mathrm{Ns}}$ & $134^{* *}$ & $21.5^{* *}$ & $7.5^{\mathrm{Ns}}$ & $123^{* *}$ \\
\hline TMPx 2637-49 & $\mathrm{OL} \times \mathrm{C} 4$ & $11.6^{* *}$ & $360^{*}$ & $225^{* *}$ & $127^{* *}$ & $16.6^{\text {tw }}$ & $6.4^{* *}$ & $95^{\mathrm{Ns}}$ \\
\hline TMPx 4698-1 & $\mathrm{OL} \times \mathrm{C} 4$ & $10.5^{* *}$ & $345^{* * *}$ & $275^{* *}$ & $130^{* *}$ & $20.0^{* *}$ & $8.5^{* *}$ & $124^{* *}$ \\
\hline TMPx 4744-1 & $\mathrm{OL} \times \mathrm{C} 4$ & $10.0^{* *}$ & $360^{*}$ & $235^{* * *}$ & $125^{* *}$ & $11.5^{*}$ & $6.0^{* *}$ & $89^{\text {vs }}$ \\
\hline TMPx 5511-2 & $\mathrm{OL} \times \mathrm{C} 4$ & $10.0^{* *}$ & $345^{* *}$ & $165^{*}$ & $118^{* *}$ & $17.8^{* *}$ & $6.0^{* *}$ & $87^{\text {Ns }}$ \\
\hline TMPx 5706-1 & $\mathrm{OL} \times \mathrm{C} 4$ & $7.5^{\mathrm{Ns}}$ & $340^{* * *}$ & $250^{* * *}$ & $133^{* *}$ & $13.6^{* *}$ & $6.8^{\mathrm{Ns}}$ & $96^{* *}$ \\
\hline TMPx 6930-1 & $\mathrm{OL} \times \mathrm{C} 4$ & $10.8^{* *}$ & $330^{* *}$ & $240^{* *}$ & $138^{* *}$ & $17.5^{* *}$ & $7.5^{\mathrm{Ns}}$ & $121^{* *}$ \\
\hline TMPx 7002-1 & $\mathrm{OL} \times \mathrm{C} 4$ & $13.0^{* *}$ & $340^{* *}$ & $270^{* * *}$ & $120^{* *}$ & $17.5^{* *}$ & $6.0^{* * *}$ & $115^{* *}$ \\
\hline $\mathrm{BT}^{\mathrm{w}}$ & & $7.0 \pm 0.2^{v}$ & $340 \pm 2$ & $171 \pm 3$ & $92 \pm 0$ & $14.0 \pm 0.2$ & $7.8 \pm 0.1$ & $100 \pm 1$ \\
\hline $\mathrm{OL}^{\mathrm{w}}$ & & $7.0 \pm 0.2$ & $370 \pm 2$ & $188 \pm 5$ & $92 \pm 0$ & $12.4 \pm 0.2$ & $7.2 \pm 0.1$ & $91 \pm 1$ \\
\hline
\end{tabular}

${ }^{2}$ Genotype response to black sigatoka according to Vakili (1968). Vegetative and bunch characteristics measured according to Swennen and De Langhe (1985). ${ }^{y}$ Height of tallest sucker.

${ }^{\mathrm{x}} \mathrm{OL}=$ 'Obino l'Ewai'; BT = 'Bobby Tannap'; $\mathrm{C} 4$ = 'Calcutta 4'; $\mathrm{PI}=$ 'Pisang lilin'.

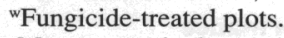

${ }^{\mathrm{V}}$ Mean + standard error $(\mathrm{n}=200)$.

Ns,",**Nonsignificant or significant at $P \leq 0.05$ or 0.01 , respectively, for multiple comparison within columns of TMPx genotypes with the respective plantain parent. Critical values of Student's $t$ distribution were adjusted by Sidak's multiplicative inequality based on $\alpha^{\prime}=1-(1-\alpha)^{1 / c}$, in which $\alpha^{\prime}$ is the level of significance required for statistical testing and $\mathrm{c}$ is the number of comparisons between the hybrids and the plantain parents (11 and 3 for OL and BT, respectively) (Sokal and Rohlf, 1981).

taller sucker at harvest, both of which are desirable traits (Table 1). The TMPx have longer fruit filling times when compared with their plantain parents. Most of the TMPx clones yield more than their fungicide-treated plantain parents. Most hybrids have fewer hands, but they generally have more fruits per bunch, which is an important yield component.

'TMPx 548-9' (Fig. 1) is an exceptional hybrid. This clone has a cylindrical pendulous bunch and large parthenocarpic fruits with yellow-orange pulp. The fruits are as long and as thick as the fruits of its plantain parent 'Obino 1'Ewai'. The performance of 'TMPX 548-9' was compared to that of its plantain parent in an independent replicated clonal evaluation trial at Onne (1991-92) (Gauhl et al., 1993). The susceptible plantain parent was maintained under fungicide and nonfungicide conditions. 'TMPx 548-9' flowered 56 to 97
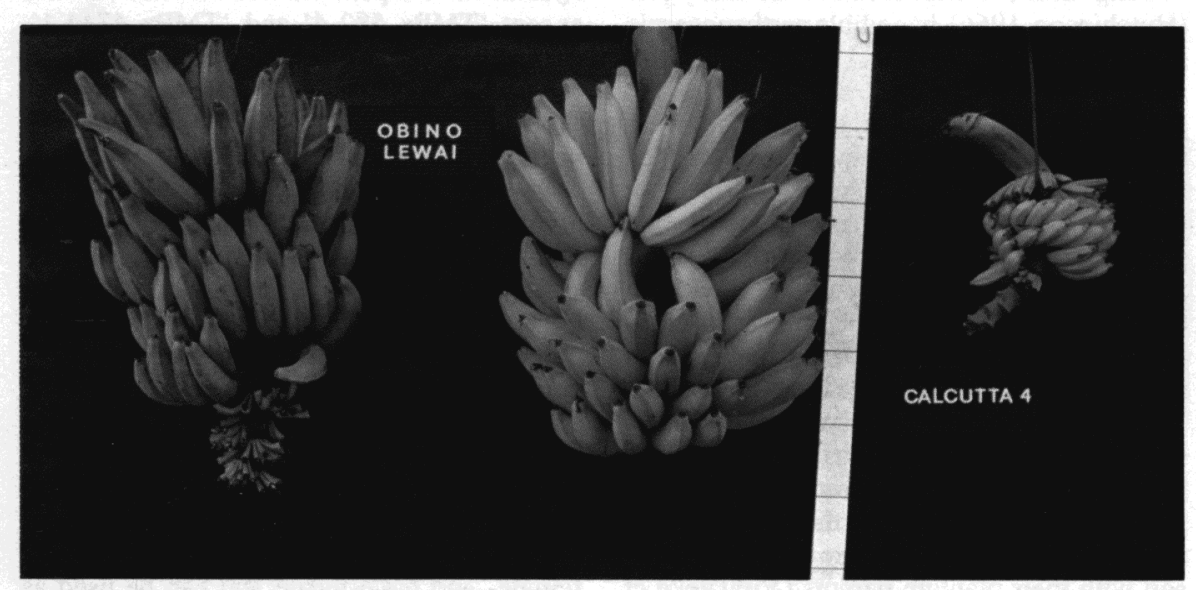

Fig. 1. Black-sigatoka-resistant $4 x$ plantain hybrid 'TMPx 548-9' (center), obtained from crossing the 3x susceptible 'Obino l'Ewai' plantain (left) with the highly resistant wild 2x 'Calcutta 4' banana (right). 'Calcutta 4' shows seed-bearing (thick) and empty (thin) fruits.

days earlier than 'Obino l'Ewai', with or without fungicide. Yield of the 'TMPx 548-9' plant crop (33.5 th ha ${ }^{-1}$ ) was $43 \%$ higher than that of the fungicide-treated 'Obino 1'Ewai' $\left(23.5 \mathrm{t} \cdot \mathrm{ha}^{-1}\right)$ and $100 \%$ higher than of the nontreated 'Obino 1'Ewai' (15.7 th.ha $\left.{ }^{-1}\right)$. Thus, the higher yield of 'TMPx 548-9' is not only attributable to black sigatoka resistance, but also may be partly due to the manifestation of heterosis in this tetraploid hybrid.

Fully matured fruits of 'Obino 1'Ewai' and 'TMPx 548-9' were evaluated by a taste panel of 12 trained Nigerian assessors for a preliminary consumer acceptability test at Onne. Fruits with green and yellow peels were fried to prepare chips and a local Nigerian dish called "dodo," respectively. Flavor and texture were similar regardless of peel color, but the fruit color of 'TMPX 548-9' was less preferred. Thus, 'TMPX 548-9' was rated "good," while
'Obino 1'Ewai' was rated "very good."

TMPx clones are currently being tested in 25 locations in collaboration with regional, national, and international research programs in Côte d'Ivoire, Ghana, Nigeria, Cameroon, Burundi, Uganda, Kenya, Zanzibar, Cuba, Dominican Republic, and Australia.

\section{Availability}

Limited numbers of in vitro plantlets are available from Leader, Plantain and Banana Improvement Program, IITA, c/o L.W. Lambourn and Co., Carolyn House, 26 Dingwall Rd., Croydon CR9 3EE, England. Recipients are asked to give appropriate recognition of the germplasm source if it is used in developing a new germplasm, parental line, or cultivar.

\section{Literature Cited}

Gauhl, F., D. Vuylsteke, K.N. Mobambo, R. Ortiz, C. Pasberg-Gauhl, and R. Swennen. 1993. Yield loss in plantain from black sigatoka leaf spot and field performance of resistant hybrids. Field Crops Res. (In press.)

Hutchinson, D.J. 1966. Translocation configurations in a diploid banana. Can. J. Genet. Cytol. 8:184-187.

Ortiz, R. and D. Vuylsteke. 1992. Inheritance of black sigatoka resistance and fruit parthenocarpy in triploid AAB plantain. Agron. Abstr. p. 109.

Simmonds, N.W. 1953. Segregations in some diploid bananas. J. Genet. 51:458-469.

Sokal, R.R and F.J. Rohlf. 1981. Biometry. 2nd ed. W.H. Freeman, New York.

Stover, R.H. 1983. Effet du Cercospora noir sur les plantains en Amerique centrale. Fruits 38:326329.

Swennen, R. 1990. Limits of morphotaxonomy: Names and synonyms of plantain in Africa and elsewhere, p. 172-210. In: R.L. Jarret (ed.). Identification of genetic diversity in the genus 
Musa. Proc. Intl. Wkshp., Los Banos, Philippines, 5-10 Sept. 1988. Intl. Network for the Improvement of Banana and Plantain, Montpellier, France.

Swennen, R. and E. De Langhe. 1985. Growth parameters of yield of plantain (Musa spp. cv. AAB). Ann. Bot. 56:197-204.

Swennen, R. and D. Vuylsteke. 1988. Female fertility in plantain (Musa spp. cv. AAB). Musarama 1:4-5.

Swennen, R. and D. Vuylsteke. 1991. Bananas in Africa: Diversity, uses and prospects for im- provement, p. 151-160. In: N.Q. Ng, P. Perrino, F. Attere, and H. Zedan (eds.). Crop genetic resources of Africa. vol. 2. Trinity Press, United Kingdom.

Swennen, R. and D. Vuylsteke. 1993. Breeding black sigatoka resistant plantains with a wild banana. Trop. Agr. (Trinidad) 70:74-77.

Vakili, N.G. 1968. Responses of Musa acuminata species and edible cultivars to infection by Mycosphaerella musicola. Trop. Agr. (Trinidad) 45:13-22.

Vuylsteke, D., R. Swennen, and E. De Langhe.
1990. Tissue culture technology for the improvement of African plantains, p. 316-337. In: R.A. Fullerton and R.H. Stover (eds.). Sigatoka leaf spot diseases ofbananas. Proc. Intl. Wkshp., San Jose, Costa Rica, 28 Mar.-1 Apr. 1989. Intl. Network for the Improvement of Banana and Plantain, Montpellier, France.

Vuylsteke, D., R. Swennen, and R. Ortiz. 1993. Development and performance of black sigatokaresistant tetraploid hybrids of plantain ( Musa spp, AAB group). Euphytica 65:33-42. 